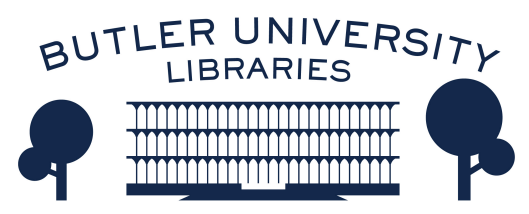

Journal of Hindu-Christian Studies

Volume 24

Article 17

November 2011

\title{
Book Review: "Influences of Ancient Hinduism on Early Christianity"
}

Reid B. Locklin

Follow this and additional works at: https://digitalcommons.butler.edu/jhcs

Part of the Religion Commons

\section{Recommended Citation}

Locklin, Reid B. (2011) "Book Review: "Influences of Ancient Hinduism on Early Christianity"," Journal of Hindu-Christian Studies: Vol. 24, Article 17.

Available at: https://doi.org/10.7825/2164-6279.1494

The Journal of Hindu-Christian Studies is a publication of the Society for Hindu-Christian Studies. The digital version is made available by Digital Commons @ Butler University. For questions about the Journal or the Society, please contact cbauman@butler.edu. For more information about Digital Commons @ Butler University, please contact digitalscholarship@butler.edu. 
surrounding the history of the Pentecostal movement in South India. These interviews also lend insight into the challenges and opportunities afforded by the distinctive ecclesiastical structure of the Pentecostal movement. While individual Pentecostal congregations are sometimes bound loosely together into short-lived partnership or interregional denominations, they are mostly autonomous, with a charismatic male leaderfounder at the head of each congregation. Modeling their style of leadership after Old Testament prophets called by God, many of these pastors are unapologetically nondemocratic. According to one pastor, "God always calls one man. That's the Bible. He never called a committee" (209). Consistent with the movement's central spiritual practice of living wholly according to God's will, a great deal of church administration is governed by the "faith principle," whereby pastors strive to depend on God alone to send the resources necessary to achieve His ends. Thus, pastors committed to this principle essentially live on spontaneous gifts from congregants, where the rituals surrounding such gift-giving bear a close resemblance to vow-related rituals found in popular Hinduism and Indian Catholicism (216217). Such erratic sources of revenue, however, do not lend themselves well to careful bookkeeping. Combined with the centralized, even autocratic form of leadership characteristic of
Pentecostal congregations, "the financial administration of the Pentecostal movement is structurally extremely susceptible to almost any kind of abuse" (219).

Bergunder's attention to the administrative nuts and bolts of the Pentecostal movement also sheds light on the somewhat contradictory effects of foreign funding, which has been the object of considerable criticism. On the one hand, Western funders (mostly American, but also Swedish and German) seeking Indian partners exacerbate the instability of interchurch cooperation by providing financial incentives for pastors to start their own churches and compete with each other for members in order to advance (mostly exaggerated) claims to robust church growth. On the other hand, visits from well-known foreign evangelists promote inter-church cooperation when local pastors band together to organize the massive rallies, "Miracle festivals," and Gospel Meetings that are the highlights of the Pentecostal calendar.

Michael Bergunder has done a great service in laying the groundwork for future studies of Pentecostalism in South India. Both the weaknesses and the strengths of the book point to exciting new avenues for further investigation.

Eliza F. Kent

Colgate University

\section{Influences of Ancient Hinduism on Early Christianity. A.L. Herman. Delhi: Motilal Banarsidass, 2009, 246 + xii pages.}

MODERN Hindu apologists have sometimes asserted that Hinduism exerted a rather direct influence on Christianity through its founder, Jesus of Nazareth, as Bradley Malkovsky reminded us in the previous issue of JHCS (23 [2010]: 4-5). Whether through an historical argument about Jesus' "lost years" in India or a theological argument about his status as an avatar and/or self-realized jīvan-mukta, such apologists have been more than happy to claim Jesus as their own, while also, at least in many cases, bemoaning the distortion of his authentic teachings by Paul of Tarsus and subsequent Christian tradition.

Despite the promise of his title, Herman offers something very close to the opposite argument in the present volume. For the "Ancient Hinduism" that represents the source of influence in this study is not the classical Hinduism of the Bhagavad-Gìtā or, much less, Śankara or another great Vedāntin; it is the ancient, sacrificial cult of Siva, as revealed in the Harappan statues and seals of the Indus Valley civilization (c. 2500-1800 BCE). And 
the "Early Christianity" that represents the object of influence is not the teaching of the historical Jesus; it is precisely the cultic traditions developed by Paul and his successors in the first three centuries of the church. Linking these two traditions is the Dionysian mystery religion of the ancient Greek and Roman empires (c. $150 \mathrm{BCE}-300 \mathrm{CE}$ ). Thus, as Herman explains in some detail, the chain of influence is not direct, but "transitive," proceeding from Harappan religion to Dionysian religion, and only therefrom to early Christianity.

First and foremost, Influences attempts to establish what Herman calls "a workable understanding of what 'influence' means" (231). He can be reckoned reasonably successful in this regard. The first chapter is dedicated to the question of "Influences and Influencing," which Herman reduces to three fundamental criteria: 1) "temporal precedence and spatial proximity" between the traditions; 2) "existential significance" such that the influencer represents the condition of the possibility of the influenced; and 3) "crucial similarity" across all points of comparison. In practice, criteria \#2 and \#3 are difficult to distinguish, insofar as it is precisely the strength and centrality of the particular similarities that establish the existential significance of the chain of influence (see esp. 212-13).

A framework for such comparison is further developed in chapter 2, where Herman suggests that religious traditions be treated as "games," therapies or algorithms for achieving freedom from suffering. Following the Buddhist model, he schematizes these algorithms according to their accounts of the soteriological problem, its cause, its solution, the way to achieve this solution and the "guaranteeing principle or person," such as the law of karma or a saviour figure (71). To this he adds four "game theory questions": 1) "Can anyone at all play this game?" 2) "Is this game finite (played to a conclusion) or infinite ... ?" 3) "Does this game contain an element of chance or fate?" 4) "Do the players of this game play with perfect information?" (74).

These criteria of influence and the "game theory" framework are first tested against well- recognized cases of intellectual influence: the influence of Thoreau and Tolstoi on Mohandas K. Gandhi and of the traditional life of the Buddha on the Christian hagiographies of the medieval saints Barlaam and Josaphat in chapter 1 , and the influence of ancient "Vedism" and "Brahmanism" on the classical "Hinduism" of the Bhagavad-Gìtā in chapter 2. Chapters 3-5 then treat, in succession, the "Religious Games" of the Indus Valley city of Harappa; the Dionysian mystery cults, particularly as depicted in Euripides' fifth-century BCE drama Bacchae; and Christian practices of initiation and Eucharist, reconstructed from the preserved writings of the $2 d$ century CE Platonist critic Celsus, supplemented by selected passages from Paul's Corinthian correspondence and the Gospel of John. From these disparate materials, Herman concludes, one can discern a clear chain of temporal and spatial succession, crucial similarities in symbols, sacrificial practices and the narrative of a saviour-figure, and significant homologies in their respective religious games including, above all, their shared character as "mystery religions." Thus, one can assert that Harappan religion influenced Christianity, such that Christianity would not exist in anything like its present form without the prior, Harappan cult of Śiva.

Herman himself concedes that this second, empirical conclusion is merely probable (221222) and indeed reckons that it "may not have been as successful" as the first, philosophical proposal (231). And he is quite right. Given the state of the evidence, his reconstructions of these ancient traditions is necessarily speculative. This problem is significantly exacerbated by his use of dated sources, as well as the intrinsic circularity of his argument: in order to establish the Harappan religion as a mystery cult, for example, he builds his interpretative framework from the Gospel of Mark, Oedipus Rex and, above all, the well-known classicist Walter Burkert's studies of Greek religion, including the cult of Dionysus! One is left wondering how many of the "crucial" similarities he uncovers can be traced to his interpretive framework itself, rather than to the empirical data of the traditions under scrutiny.

More problematic still is his too-sharp 
contrast between religious "absolutism" and "relativism," and his claim that the Christian claim and indeed any claim to originality or uniqueness rests exclusively upon its claim to be "uninfluenced." The examples he provides, such as the "absolutist" decision of the Catholic Church to remove Barlaam and Josaphat from the canon of saints in the 1960s, or the wholly derivative, fundamentally non-Hindu character of Gandhi's doctrine of satyāgraha, are entirely unpersuasive (see 30-32, 52-55). Herman appears unable to sustain any notion of a genuinely original synthesis, or to concede the possibility of discerning between authentic and inauthentic influences. Intellectual influence is substantively identified with plagiarism, such that a religious tradition that bears any "existentially significant" mark of another tradition can, seemingly, claim no integrity of its own.

Such a position strikes this reader as, well, absolutist. Hence, Herman's volume never rises above the level of a relatively clear, intriguing and provocative thought-experiment. Readers seeking more credible historical reconstructions or more nuanced interpretative judgments are advised to look elsewhere.

Reid B. Locklin

St. Michael's College

University of Toronto

\section{Three Hundred Verses of Bhartrhari. With Sanskrit Text, English Translation, and Christian Commentary. Rev. Dr.-Dr. Jacob Kattackal. Department of Publications of Paurastya Vidyapitham. Vadavathoor, Kottayam, India. 2008, 216 pp.}

BHARTṛHARI ( $7^{\text {th }}$ century or early) was a famous and to some extent mythic author of a rich body of Indian poetry. He authored a most famous collection of (more or less) 300 verses known as the Satakatrayam or even more simply "the Bhartrhari." This work is divided by three themes, nìti (right living, morality), vairāgya (detachment), and śrnigāra (desire, love). If treated as a whole, it offers a broad view of values basic to human and religious living. It is therefore a text ripe for comparative theological study.

Jacob Kattackal is a prolific author of many small books in English and Malayalam. Though unavailable to this reviewer, prior volumes on the İsa Upanișad, the Kața Upanișad, and Bhagavad Gìtā by their subtitles promise text, translation, and Christian commentary. The current volume is the latest entry in this intriguing project of Christian-Hindu interreligious understanding.

Kattackal offers a new translation of the three hundred verses. He appends some careful notes on variant readings, but on the whole his translation is loose, often a paraphrase and at times awkward. The reader interested in Bhartrhari as a poet is advised to consult Barbara Stoler Miller's admirable Bhartrhari: Poems (Columbia University Press, 1967).

In this case at least, Kattackal's "Christian commentary" is directly the practice of interpretation by the pairing of texts, the inclusion after each verse of Bhartrhari of a Biblical verse or verses. No rationale for the choice of pairings is given at the verses, and there is no introduction or subsequent essay in the volume. In some cases similarity in theme seems the motivation, while in others contrast appears key. Three examples must suffice to give a feel for the project. A first paired reading seems to accentuate the futility of riches:

"A wealthy person is taken to be noble, learned, well-versed in Sacred Scripture and even virtuous - even though, in truth, he possesses none of these qualities! That wealthy person is requested to speak in public, and he is declared to be goodlooking, even though the contrary is the truth! To put it bluntly, all the so-called 